\title{
Sistem Pembobotan Berdasarkan Teknik Analisis Korelasi Untuk Penerimaan Siswa Baru Menggunakan Metode SAW
}

\author{
Nimas Dian Fitria, Aji Prasetya Wibawa* \\ Fakultas Teknik, Pendidikan Kejuruan, Universitas Negeri Malang, Malang, Indonesia \\ Email: ${ }^{1}$ nimasdynftr@gmail.com, ${ }^{2}$ aji.prasetya.ft@um.ac.id \\ Email Penulis Korespondensi: emailpenuliskorespondensi@email.com
}

\begin{abstract}
Abstrak-Penerimaan Siswa Baru (PSB) adalah program tahunan yang diadakan oleh pihak sekolah untuk menjaring peserta didiknya, sesuai dengan kriteria yang diinginkan oleh pihak sekolah. Salah satu alternatif metode untuk menentukan peringkat calon siswa baru adalah dengan menggunakan metode SAW (Simple Additive Weighting). Untuk mengurangi subjektivitas yang muncul dalam penggunaan metode SAW, digunakan teknik analisis korelasi yang berguna untuk mengetahui tingkat korelasi setiap kriteria terhadap penerimaan siswa baru. Berdasarkan hasil penelitian, didapatkan bahwa kriteria penghasilan orang tua memiliki bobot tertinggi $(0,851)$, disusul dengan nilai matematika $(0,845)$, nilai bahasa inggris $(0,831)$, nilai fisika $(0,577)$, kesamaptaan $(0,539)$, dan terakhir peminatan $(0,282)$. Sementara itu, hasil berdasarkan perangkingan menggunakan metode SAW didapatkan hasil bahwa siswa A3 (Alternatif 3) memiliki nilai V1 terbesar dibandingkan dengan alternatif lain, yaitu sebesar 3,54. Sehingga dapat disimpulkan bahwa siswa A3 merupakan siswa dengan hasil nilai akhir terbaik dibandingkan dengan siswa lainnya.
\end{abstract}

Kata Kunci: Penerimaan Siswa Baru; Metode SAW; Teknik Analisis Korelasi; Sistem Pendukung Keputusan; Matriks Keputusan

Abstract-New Student Admission (PSB) is an annual program held by the school to get students, according to the criteria desired by the school. One of alternatif method to determine the ranking of prospective new students is to use the SAW (Simple Additive Weighting) method. To reduce the subjectivity that arises in the use of the SAW method, a correlation analysis technique is used which is useful for knowing the level of correlation of each criterion on new student admissions. Based on the results of the research, it was found that the parents' income criteria had the highest weight $(0.851)$, followed by math scores (0.845), English scores (0.831), physics scores (0.577), physical ability (0.539), and finally student interest (0.282). Meanwhile, the results based on ranking using the SAW method showed that students A3 (Alternatif 3) had the largest V1 value compared to other alternatifs, which was 3.54. So it can be concluded that A3 are students with the best final scores compared to other students.

Keywords: New Student Admission; SAW Method; Correlation Analytics Technique; Decision Support Sistem; Decision Matrix

\section{PENDAHULUAN}

Penerimaan Siswa Baru (PSB) adalah program tahunan yang diadakan oleh pihak sekolah untuk menjaring peserta didiknya. Penerimaan peserta didik baru ini merupakan suatu proses administrasi yang terjadi setiap tahun untuk menyeleksi calon siswa berdasarkan nilai akademik agar dapat melanjutkan Pendidikan pada jenjang yang lebih tinggi, dan juga merupakan salah satu proses yang ada di instansi Pendidikan seperti sekolah yang berguna untuk menyaring calon siswa yang terpilih sesuai kriteria yang ditentukan oleh sekolah tersebut untuk menjadi peserta didiknya [1]. Dalam menentukan peserta didik yang lolos, setiap sekolah memiliki kriteria yang berbeda-beda sesuai dengan kriteria peserta didik yang diinginkan. Hal tersebut ditentukan berdasarkan tujuan yang ingin dicapai oleh pihak sekolah. Pada dasarnya proses administrasi untuk melakukan penjaringan peserta didik baru dilakukan dengan cara, setiap peserta didik melakukan pendaftaran, lalu dilakukan penseleksian terhadap siswa-siswa tersebut. penseleksian calon peserta didik baru didasarkan pada kriteria-kriteria yang telah ditentukan oleh pihak sekolah. Berdasarkan hal tersebut proses penerimaan dilakukan dengan cara melakukan perangkingan berdasarkan kriteria-kriteria yang telah ditentukan oleh pihak sekolah.

Dengan jumlah pendaftar yang mencapai 900 siswa, maka akan sangat sulit untuk melakukan pengambilan keputusan untuk menentukan peserta mana yang lebih baik. Melakukan perhitungan manual untuk menentukan perangkingan membutuhkan waktu yang relatif lama dan meningkatkan potensi untuk terjadinya suatu keslahan dalam prosesnya. Sehingga berdasarkan hal tersebut diperlukan sebuah metode yang dapat melakukan perhitungan dalam penentuan siswa baru yang diterima sesuai dengan kriteria pihak sekolah, dalam waktu yang relative singkat dan minim kesalahan.

Berdasarkan permasalahan tersebut, maka dibutuhkan suatu metode yang tepat dalam melakukan sebuah keputusan dalam penerimaan siswa baru. Salah satu dari metode yang dapat diterapkan dalam sistem pendukung keputusan adalah metode SAW (Simple Additive Weighting). Metode SAW merupakan salah satu metode penyelesaian masalah MDAM (Multiple Atribut Decision Making) yang sering disebut dengan istilah metode penjumlahan berbobot [2]. Konsep dasar dari metode SAW adalah mencari penjumlahan terbobot dari rating kinerja pada setiap alternatif dari semua atribut, di mana metode SAW membutuhkan proses normalisasi matriks keputusan (X) ke suatu skala yang dapat diperbandingkan dengan semua rating alternatif yang ada [2]. Dalam penelitian ini metode SAW diterapkan untuk menentukan calon peserta didik yang terbaik yang sesuai dengan bobot kriteria yang telah ditentukan berdasaran analisa sebelumnya [3]. 
Permasalahan lain muncul ketika jumlah besaran nilai dalam pembobotan setiap kriteria masih mengandung subjektivitas pihak sekolah. Subjektivitas sendiri adalah suatu penafsiran yang muncul berdasarkan suatu asumsi pribadi, di mana dalam praktiknya, hal tersebut menjadi salah satu faktor terjadinya kesalahan dalam penafsiran [4]. Sekolah cenderung menentukan besaran nilai dalam pembobotan tanpa memperhitungkan dasar yang pasti dalam menentukan pembobotan itu sendiri. Sehingga penggunaan metode SAW sebagai sistem pendukung keputusan dianggap lemah. Oleh karenanya, beberapa penelitian yang menggunakan metode SAW sebagai sistem pendukung keputusannya, cenderung mengkombinasikan beberapa metode selain metode SAW itu sendiri. Seperti penelitian yang dilakukan oleh Purwitasari dan Pribadi [5] , di mana mengkombinasikan metode SAW dan AHP (Analytic Hierarchy Process) untuk menentukan pembobotan kriteria yang ditentukan dengan asumsi bahwa metode tersebut menentukan pembobotan berdasar pada matriks perbandingan pasangan dengan melakukan analisis konsistensi. Peneliatian lain yang dilakukan oleh Nurzahputra dkk [6], di mana dalam penelitian tersebut, peneliti mengkombinaskan metode SAW dan K-Means Clustering unuk membuat sistem pendukung keputusan pemilihan line-up pemain sepak bola, dengan asumsi penambahan algorithm $K$-Means yang diterapkan dapat menghasilkan keputusan yang lebih baik daripada sistem lainnya, sehingga pelatih dapat menentukan secara lebih objektif. Sementara itu penelitian yang dilakukan oleh Prahesti dkk [7], mengkombinasikan metode SAW dan AHP-Electre untuk menentukan rekomendasi pemilihan Sekolah Menengah Atas (SMA) sederajat Kota Malang, di mana metode AHP digunakan sebagai pemberian pembobotan, metode electre digunakan sebagai pengelompokkan alternatif, dan metode SAW digunakan sebagai alternatif perangkingan.

Berdasarkan hal tersebut, dalam penelitian ini metode SAW dikombinasikan dengan teknik analisis korelasi. Teknik analisis korelasi merupakan teknik statistika yang meneliti adanya hubungan antar dua variabel yang merupakan hubungan searah, bukan merupakan hubungan timbal balik [8]. Berdasarkan pemaparan tersebut maka, penerapan teknik analisis korelasi dalam penelitian digunakan untuk mengetahui hubungan antara atribut kriteria dengan keputusan penerimaan siswa berdasarkan benefit dan cost-nya. Kemudian hasil dari uji analisis korelasi tersebut digunakan sebagai acuan besaran pembobotan setiap kriteria yang ditentukan sebelumnya. Penggunaan metode SAW dengan pembobotan berdasarkan statistic korelasi untuk menentukan alternatif terbaik dalam memberikan rekomendasi penerimaan siswa baru, diharapkan mampu mengurangi subjektivitas dalam penentuan bobot oleh pihak sekolah.

\section{METODOLOGI PENELITIAN}

\subsection{Tahapan Penelitian}

Penelitian ini termasuk kedalam sebuah penelitian yang merujuk kepada suatu Sistem Pendukung Keputusan (SPK). Sistem Pendukung Keputusan adalah sistem penghasil informasi spesifik yang ditujukan untuk memecahkan suatu masalah tertentu yang harus dipecahkan [9]. Selain itu SPK dapat membantu menyelesaikan sebuah permasalahan, di mana memperhitungkan kriteria-kriteria pengambilan keputusan untuk membantu, mempercepat dan mempermudah dalam proses pengambilan keputusan [8].

Sementara itu, teknik analisis korelasi digunakan sebagai metode untuk mengetahui apakah kriteria yang digunakan dalam penerimaan siswa baru di SMK Telkom Malang memiliki subjektivitas atau tidak. Sehingga dilakukan suatu uji korelasi terhadap kriteria yang digunakan dengan keputusan penerimaan siswa baru, dengan menggunakan teknik analisis korelasi dengan menggunakan software application, yaitu SPSS IBM 20. Berdasarkan pengujian tersebut, maka akan diketahui signifikansi besaran hubungan yang dimiliki oleh setiap kriteria dengan keputusan diterimanya calon siswa. Adapun tahapan penelitian diuraikan pada gambar 1 sebagai berikut.

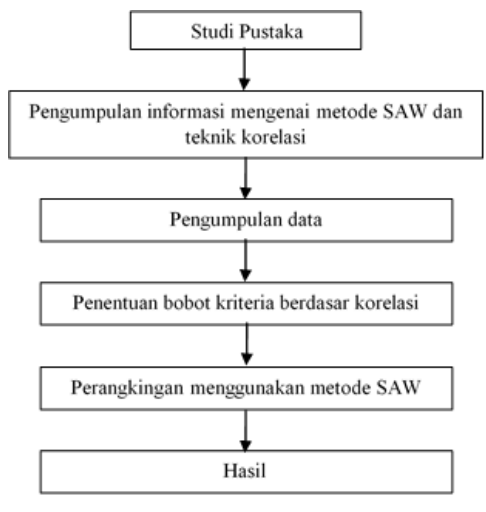

Gambar 1. Tahapan Penelitian

1. Studi Pustaka

Pencarian informasi terhadap penelitian terdahulu mengenai permasalahan dan penggunaan metode yang akan di gunakan dalam penelitian yang bersumber pada buku, jurnal, maupun sumber lainnya. 
2. Pengumpulan informasi terkait metode SAW dan teknik korelasi

Pengumpulan informasi yang bersifat sebagai penguatan sebelum menggunakan metode SAW dan teknik korelasi dalam penelitian.

3. Pengumpulan data

Data didapatkan berdasarkan dokumen penerimaan siswa baru yang berisi data hasil tes sesuai dengan kriteria yang telah ditentukan oleh sekolah.

4. Penentuan bobot kriteria berdasarkan korelasi

Pada tahap ini kriteria yang sudah ditentukan oleh pihak sekolah di uji tingkat korelasinya terhadap hasil tes penerimaan siswa baru dengan menggunakan software application, yaitu SPSS IBM 20.

5. Perangkingan menggunakan metode SAW

Pada tahap ini akan dilakukan penghitungan dimulai dari menetukan rating kecocokan setiap alternatif hingga mendapatkan data rangking sebagai alternatif terbaik

6. Hasil

Berdasarkan data yang sudah diolah dengan menggunakan teknik korelasi dan metode SAW maka didapatkan hasil perangkingan alternatif terbaik siswa dengan nilai terbaik.

\subsection{Pembobotan Menggunakan Teknik Analisis Korelasi}

Dalam penelitian ini, bobot ditentukan dari hasil uji analisis korelasi, di mana untuk menentukan pembobotan didasarkan dari ada atau tidaknya hubungan yang signifikan antara setiap kriteria dengan keputusan penerimaan calon siswa baru. Penghitungan yang dilakukan untuk mengetahui tingkat korelasi antar kriteria didapatkan dengan menggunakan rumus berikut.

$$
r=\frac{\Sigma x y-\frac{(\Sigma x)(\Sigma y)}{n}}{\sqrt{\left(\Sigma x^{2} \frac{(\Sigma x)^{2}}{n}\right)\left(\Sigma y^{2}-\frac{(\Sigma y)^{2}}{n}\right)}}
$$

Tingkat urgenitas bobot sebagai dasar interprestasi hasil uji analisis korelasi disajikan pada Tabel 1 sebagai berikut.

Tabel 1. Interpretasi Hasil Korelasi

\begin{tabular}{cc}
\hline $\mathrm{r}$ & Interpretasi \\
\hline 0 & Tidak berkorelasi \\
$0,01-0,20$ & Sangat rendah \\
$0,21-0,40$ & Rendah \\
$0,41-0,60$ & Agak rendah \\
$0,61-0,80$ & Cukup \\
$0,81-0,99$ & Tinggi \\
1 & Sangat tinggi \\
\hline
\end{tabular}

\subsection{Metode SAW}

Metode SAW (Simple Additive Weighting) atau sering disebut dengan metode pembobotan adalah salah satu metode dalam Sistem Pendukung Keputusan dengan konsep dasar mencari penjumlahan terbobot dari rating kinerja pada setiap alternatif pada semua atribut [10]-[14]. Metode ini membutuhkan proses normalisasi matriks keputusan ke suatu skala yang dapat diperbandingkan dengan semua rating alternatif yang ada [3]. Studi kasus dilakukan di SMK Telkom Malang, sehingga kriteria yang digunakan dalam penelitian ini adalah kriteria yang digunakan dalam penerimaan siswa baru yang berlaku di SMK Telkom Malang. Terdapat enam kriteria yang digunakan sebagai pertimbangan dalam penerimasan siswa baru, beserta bobot yang telah ditentukan oleh pihak sekolah yang ditunjukkan pada tabel 2 berikut.

Tabel 2. Data Kriteria dan Bobot Penerimaan Siswa Baru

\begin{tabular}{ccc}
\hline Kriteria & Keterangan & Bobot \\
\hline $\begin{array}{c}\text { Penghasilan } \\
\text { orang tua }\end{array}$ & $\begin{array}{c}\text { Didapatkan } \\
\text { berdasarkan } \\
\text { wawancara dengan } \\
\text { orang tua } \\
\text { Peminatan siswa }\end{array}$ & $30 \%$ \\
& $\begin{array}{c}\text { Didapatkan } \\
\text { berdasarkan } \\
\text { wawancara dengan } \\
\text { calon siswa } \\
\text { Nidapatkan dari tes } \\
\text { siswa }\end{array}$ & $25 \%$ \\
\hline
\end{tabular}


ISSN 2614-5278 (media cetak), ISSN 2548-8368 (media online)

Available Online at https://ejurnal.stmik-budidarma.ac.id/index.php/mib DOI 10.30865/mib.v5i3.3080

\begin{tabular}{ccc}
\hline Kriteria & Keterangan & Bobot \\
\hline Nilai Fisika & $\begin{array}{c}\text { Didapatkan dari tes } \\
\text { siswa }\end{array}$ & $13 \%$ \\
$\begin{array}{c}\text { Nilai Bahasa } \\
\text { Inggris } \\
\text { Kesamaptaan (tes } \\
\text { fisik) }\end{array}$ & $\begin{array}{c}\text { Didapatkan dari tes } \\
\text { siswa } \\
\text { Didapatkan dari } \\
\text { hasil tes siswa }\end{array}$ & $10 \%$ \\
\hline
\end{tabular}

Setiap kriteria ditentukan bobotnya oleh pihak sekolah. Sehingga dalam hal ini bobot dalam setiap kriteria mengandung subjektivitas dari pihak sekolah itu sendiri. Selanjutnya kriteria tersebut dikaji ulang dengan menggunakan teknik analisis korelasi, kemudian hasil yang diperoleh dihitung menggunakan metode SAW untuk mendapatkan alternatif perangkingan terbaik. Langkah dan perhitungan dengan menggunakan metode SAW ditunjukkan pada gambar 2 sebagai berikut.

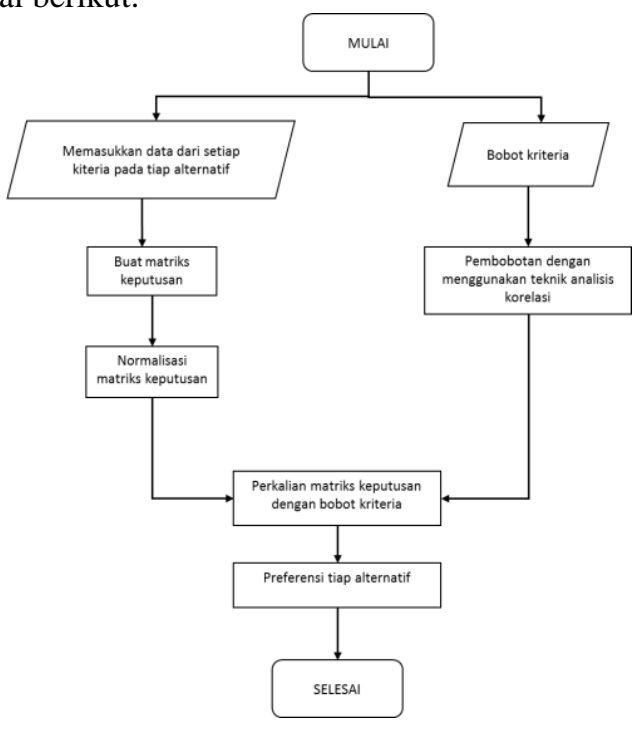

Gambar 2. Skema Metode SAW

Berdasarkan gambar 2, tahap awal yaitu menentukan kriteria-kriteria yang akan dijadikan acuan dalam pengambilan keputusan $(\mathrm{Cj})$ dan menentukan bobot kriteria. Selanjutnya membuat matriks keputusan berdasarkan kriteria $(\mathrm{Cj})$, kemudian melakukan normalisasi matriks berdasarkan persamaan yang disesuaikan dengan jenis atribut (benefit attribute or cost attribute) sehingga diperoleh matriks ternormalisasi Rij. Setelah diperoleh matriks ternormalisasi, maka diperoleh hasil akhir proses perankingan, yaitu penjumlahan dari perkalian matriks ternormalisasi Rij dengan vector bobot sehingga diperoleh preferensi nilai terbesar yang dipilih sebagai alternatif terbaik (Ai) sebagai solusi. Lebih lanjut penghitungan dengan menggunakan metode SAW memenuhi tahapan sebaga berikut.

1) Proses normalisasi matriks keputusan

Metode SAW (Simple Additive Weighting) membutuhkan proses normalisasi matriks keputusan (X) dengan skala yang dapat dibandingkan dengan semua peringkat alternatif yanga ada [15]. Dalam tahapan ini perlu dilakukan perhitungan dengan menggunakan normalisasi formula berdasarkan kategori kriteria yaitu benefit dan cost [16]. Untuk melakukan normasilasi matriks keputusan maka digunakan persamaan sebagai berikut.

$$
r_{i j}= \begin{cases}\frac{X_{i j}}{\operatorname{Max} X_{i j}} & \text { (jika nilai terbesar adalah nilai terbaik) } \\ \frac{\operatorname{Min} X_{i j}}{X_{i j}} & \text { (jika nilai terkecil adalah nilai terbaik) }\end{cases}
$$

Di mana rij adalah rating kinerja ternormalisasi dari alternatif Ai pada atribut $\mathrm{Cj} ; \mathrm{i}=1,2, \ldots, \mathrm{m}$ dan $\mathrm{j}=1$, $2, \ldots, n$, dengan nilai preferensi untuk setiap alternatif (Vi).

2) Perangkingan

Perangkingan digunakan untuk mengetahui alternatif Ai terbaik sari suatu kelompok. Nilai preferensi untuk setiap alternatif (Vi) ditunjukkan dalam persamaan sebagai berikut.

$$
V_{i}=\sum_{j=i}^{n} w_{j} r_{i j}
$$

Nilai Vi yang lebih besar mengindikasikan bahwa alternatif Ai lebih terpilih, di mana Vi adalah rangking untuk setiap alternatif wj adalah nilai bobot dari setiap kriteria dan rij adalah nilai rating kinerja ternormalisasi [4]. 


\section{HASIL DAN PEMBAHASAN}

\subsection{Menentukan Kriteria Pengambilan Keputusan}

Tahap pertama dalam menerapkan metode SAW (Simple Additive Weighting) adalah menentukan kriteria untuk selanjutnya dilakukan pembobotandan perangkingan rekomendasi alternatif yang dituju. Kriteria pengambilan keputusan dalam penelitian ini didasarkan pada kriteria yang telah diterapkan di SMK Telkom Malang dalam melakukan penerimaan siswa baru. SMK Telkom Malang menetapkan enam kriteria yang digunakan sebagai acuan untuk melakukan penerimaan siswa baru, yang ditunjukkan pada Tabel 3.

Tabel 3. Kriteria dan Penilaian

\begin{tabular}{lll}
\hline No & Keterangan & Penilaiaan \\
\hline 1 & Penghasilan Orang Tua & $1=$ 'tinggi' $(>$ Rp. 6.000.000) \\
& & $2=$ 'sedang' $(\geq$ Rp. 3.000.000, \\
& & Rp. 6.000.000) \\
& & $3=$ 'rendah' $(<$ Rp. 3.000.000) \\
& & $=$ minat 'tinggi' \\
2 & & $=$ minat 'sedang' \\
& Keminatan Siswa & $3=$ minta 'rendah' \\
& & Interval 0-100 \\
3 & Nilai Matematika & Interval 0-100 \\
4 & Nilai Bahasa Inggris & Interval 0-100 \\
5 & Nilai Fisika & $1=$ nilai 'sangat tinggi' \\
6 & Kesamaptaan (tes fisik) & $2=$ nilai 'tinggi' \\
& & $3=$ nilai 'sedang' \\
& & $4=$ nilai 'kurang' \\
& & $5=$ nilai 'sangat kurang' \\
\hline
\end{tabular}

Merujuk pada metode SAW yang memiliki ketentuan, dikatakan atribut benefit apabila atribut banyak memberikan keuntungan bagi pengambil keputusan, sedangkan atribut biaya merupakan atribut yang banyak memberikan cost jika nilainya semakin besar bagi pengambil keputusan [17], maka dalam penelitian ini kriteriakriteria yang sudah dijadikan acuan tersebut digolongkan menjadi atribut benefit dan atribut cost.

Untuk kriteria yang memenuhi atribut benefit adalah kriteria, yaitu (1) Nilai matematika, (2) Nilai bahasa inggris, dan (3) nilai fisika. Ketiga nilai tersebut memiliki interval nilai 0-100, di mana menjadi atribut benefit karena semakin tinggi nilai yang dimiliki oleh calon siswa, maka peluang untuk diterima semakin besar. Sementara itu, untuk kriteria yang memenuhi atribut cost adalah kriteria, yaitu (a) penghasilan orang tua, (b) keminatan siswa, dan (c) kesamaptaan. Ketiga nilai tersebut memiliki interval nilai yang berbeda, karena kriteria-kriteria tersebut didapat berdasarkan kuisioner atau nilai praktik calon siswa.

\subsection{Menentukan Rating Kecocokan Setiap Alternatif}

Sebelum menentukan rating kecocokan setiap alternatif, maka dibutuhkan perumusan bobot terlebih dahulu dari kriteria-kriteria yang sudah ditentukan. Pembobotan dalam penelitan ini menggunakan teknik analisis korelasi produk momen. Kegunaan dari korelasi produk momen adalah untuk menyatakan ada atau tidaknya hubungan yang signifikan antara variabel satu dengan lainnya, dan untuk menyatakan besarnya sumbangan variabel satu terhadap yang lainnya yang dinyatakan dalam persen [18]. Sehingga, pembobotan didapatkan dengan mencari hubungan-hubungan antara setiap kriteria dengan keputusan penerimaan siswa baru. Untuk mendapatkan besaran nilai korelasi dilakukan dengan bantuan software SPSS IBM 20 dengan hasil pembobotan seperti yang ditunjukkan oleh tabel 4 sebagai berikut.

Tabel 4. Hasil Pembobotan

\begin{tabular}{ccc}
\hline Kriteria & Keterangan & Besaran Bobot \\
\hline C1 & Penghasilan Orang Tua & 0,851 \\
C2 & Nilai Matematika & 0,845 \\
C3 & Nilai Bahasa Inggris & 0,831 \\
C4 & Nilai Fisika & 0,577 \\
C5 & Kesamaptaan (tes fisik) & 0,539 \\
C6 & Peminatan & 0,282 \\
\hline
\end{tabular}

Hasil pembobotan tersebut didapatkan dari menghitung besaran korelasi dari setiap kriteria. Nilai tersebut didapatkan dari penghitungan dengan menggunakan sample sebanyak 30 siswa yang diambil secara acak untuk dicari besaran angka korelasi dengan hasil penerimaan. Setelah dilakukan uji korelasi (pearson correlation) didapatkan nilai bobot seperti pada Tabel 4, di mana peminatan memili nilai besaran paling kecil, yakni 0,282. 
Sementara penghasilan orang tua memiliki nilai besaran paling tinggi, yakni 0,851 , disusul pada urutan berikutnya nilai matematika, nilai bahasa inggris, nilai fisika, dan kesamaptaan (tes fisik).

Angka besaran yang disajikan pada Tabel 4 memiliki makna seberapa kuat korelasi dari setiap kriteria. Hal tersebut didapatkan sesuai dengan tabel interpretasi nilai korelasi variabel pada Tabel 1. Berdasarkan tabel tersebut maka dapat disimpulkan bahwa tiga kriteria mendapatkan tingkat hasil korelasi yang tinggi, yaitu penghasilan orang tua, nilai matematika, dan nilai bahasa inggris. Sementara itu dua kriteria mendapatkan tingkat hasil korelasi yang agak rendah, yaitu nilai fisika dan kesamaptaan (tes fisik). Terakhir, kriteria peminatan siswa memiliki tingkat hasil korelasi rendah.

Setelah mendapatkan besaran bobot dari setiap kriteria, melalui uji korelasi, selanjutnya adalah menentukan rating kecocokan dari data awal dari setiap alternatif, di mana diambil 5 sampel calon siswa baru, yang ditunjukkan oleh Tabel 5 sebagai berikut.

Tabel 5. Alternatif Rating Kecocokan

\begin{tabular}{cccccccc}
\hline No & Nama & C1 & C2 & C3 & C4 & C5 & C6 \\
\hline 1 & Alternatif 1 & 1 & 83 & 90 & 78 & 5 & 11 \\
2 & Alternatif 2 & 1 & 85 & 75 & 72 & 2 & 11 \\
3 & Alternatif 3 & 1 & 90 & 64 & 88 & 1 & 22 \\
4 & Alternatif 4 & 2 & 78 & 84 & 78 & 1 & 15 \\
5 & Alternatif 5 & 1 & 78 & 85 & 74 & 2 & 24 \\
\hline
\end{tabular}

\subsection{Membuat Matriks Keputusan}

Matriks keputusan dibuat berdasarkan data normalisasi yang telah dibuat sebelumnya, sebagai berikut.

$$
X=\left[\begin{array}{llllll}
1 & 83 & 90 & 78 & 5 & 11 \\
1 & 85 & 75 & 72 & 2 & 11 \\
1 & 90 & 64 & 88 & 1 & 22 \\
2 & 78 & 84 & 78 & 1 & 15 \\
1 & 78 & 85 & 74 & 2 & 24
\end{array}\right]
$$

Setelah dibuat matriks keputusan $\mathrm{X}$, maka selanjutnya dilakukan normalisasi terhadap matriks $\mathrm{X}$ dengan cara menghitung nilai rating kinerja ternormalisasi $\left(\mathrm{R}_{\mathrm{ij}}\right)$ dari alternatif $\left(\mathrm{A}_{\mathrm{i}}\right)$ pada kriteria $\left(\mathrm{C}_{\mathrm{j}}\right)$ [19].

\section{a. Alternatif 1}

$$
\begin{aligned}
& R_{11}=\frac{\operatorname{Min}(1,1,1,2,1)}{1}=\frac{1}{1}=1 \\
& R_{12}=\frac{83}{\operatorname{Max}(83,85,90,78,78)}=\frac{83}{90}=0.92 \\
& R_{13}=\frac{90}{\operatorname{Max}(90,75,64,84,85)}=\frac{90}{90}=1 \\
& R_{14}=\frac{78}{\operatorname{Max}(78,72,88,78,74)}=\frac{78}{88}=0,89 \\
& R_{15}=\frac{\operatorname{Min}(5,2,1,1,2)}{5}=\frac{1}{5}=0.2 \\
& R_{16}=\frac{\operatorname{Min}(11,11,22,15,24)}{11}=\frac{11}{11}=1
\end{aligned}
$$

\section{b. Alternatif 2}

$$
\begin{aligned}
& R_{21}=\frac{\operatorname{Min}(1,1,1,2,1)}{1}=\frac{1}{1}=1 \\
& R_{22}=\frac{85}{\operatorname{Max}(83,85,90,78,78)}=\frac{83}{90}=0.94 \\
& R_{23}=\frac{75}{\operatorname{Max}(90,75,64,84,85)}=\frac{75}{90}=0.83 \\
& R_{24}=\frac{72}{\operatorname{Max}(78,72,88,78,74)}=\frac{72}{88}=0,81 \\
& R_{25}=\frac{\operatorname{Min}(5,2,1,1,2)}{2}=\frac{1}{2}=0.5 \\
& R_{26}=\frac{\operatorname{Min}(11,11,22,15,24)}{11}=\frac{11}{11}=1
\end{aligned}
$$

\section{c. Alternatif 3}

$$
R_{31}=\frac{\operatorname{Min}(1,1,1,2,1)}{1}=\frac{1}{1}=1
$$


ISSN 2614-5278 (media cetak), ISSN 2548-8368 (media online)

Available Online at https://ejurnal.stmik-budidarma.ac.id/index.php/mib DOI 10.30865/mib.v5i3.3080

$$
\begin{aligned}
& R_{32}=\frac{90}{\operatorname{Max}(83,85,90,78,78)}=\frac{90}{90}=1 \\
& R_{33}=\frac{64}{\operatorname{Max}(90,75,64,84,85)}=\frac{64}{90}=0.71 \\
& R_{34}=\frac{88}{\operatorname{Max}(78,72,88,78,74)}=\frac{88}{88}=1 \\
& R_{35}=\frac{\operatorname{Min}(5,2,1,1,2)}{2}=\frac{1}{1}=1 \\
& R_{36}=\frac{\operatorname{Min}(11,11,22,15,24)}{22}=\frac{11}{22}=0.5
\end{aligned}
$$

\section{d. $\quad$ Alternatif 4}

$$
\begin{aligned}
& R_{41}=\frac{\operatorname{Min}(1,1,1,2,1)}{2}=\frac{1}{2}=0.5 \\
& R_{42}=\frac{78}{\operatorname{Max}(83,85,90,78,78)}=\frac{78}{90}=0.87 \\
& R_{43}=\frac{84}{\operatorname{Max}(90,75,64,84,85)}=\frac{84}{90}=0.93 \\
& R_{44}=\frac{78}{\operatorname{Max}(78,72,88,78,74)}=\frac{78}{88}=0.89 \\
& R_{45}=\frac{\operatorname{Min}(5,2,1,1,2)}{1}=\frac{1}{1}=1 \\
& R_{46}=\frac{\operatorname{Min}(11,11,22,15,24)}{15}=\frac{11}{15}=0.73
\end{aligned}
$$

\section{e. $\quad$ Alternatif 5}

$$
\begin{aligned}
& R_{51}=\frac{\operatorname{Min}(1,1,1,2,1)}{1}=\frac{1}{1}=1 \\
& R_{52}=\frac{78}{\operatorname{Max}(83,85,90,78,78)}=\frac{78}{90}=0.87 \\
& R_{53}=\frac{85}{\operatorname{Max}(90,75,64,84,85)}=\frac{85}{90}=0.94 \\
& R_{54}=\frac{74}{\operatorname{Max}(78,72,88,78,74)}=\frac{74}{88}=0.89 \\
& R_{55}=\frac{\operatorname{Min}(5,2,1,1,2)}{2}=\frac{1}{2}=0.5 \\
& R_{56}=\frac{\operatorname{Min}(11,11,22,15,24)}{11}=\frac{11}{24}=0.45
\end{aligned}
$$

Berdasarkan perhitungan di atas, maka matriks ternormalisasi didapatkan sebagai berikut.

$$
X=\left[\begin{array}{cccccc}
1 & 0.92 & 1 & 0.89 & 0.2 & 1 \\
1 & 0.94 & 0.83 & 0.81 & 0.5 & 1 \\
1 & 1 & 0.71 & 1 & 1 & 0.5 \\
0.5 & 0.87 & 0.93 & 0.89 & 1 & 0.73 \\
1 & 0.87 & 0.89 & 0.89 & 0.5 & 0.45
\end{array}\right]
$$

\subsection{Perangkingan Alternatif Terbaik}

Untuk memperoleh alternatif terbaik sebagai acuan penerimaan siswa baru, maka dibuat perkalian matriks $\mathrm{W} \times \mathrm{R}$, di mana $\mathrm{W}$ merupakan bobot yang telah ditentukan, sementara $\mathrm{R}$ adalah matriks ternormalisasi dari setiap alternatif-alternatif yang ada [17], sementara $\mathrm{V}$ adalah hasil nilai perkalian bobot (W) dengan matriks ternormalisasi $(\mathrm{R})$ dari setiap alternatif.

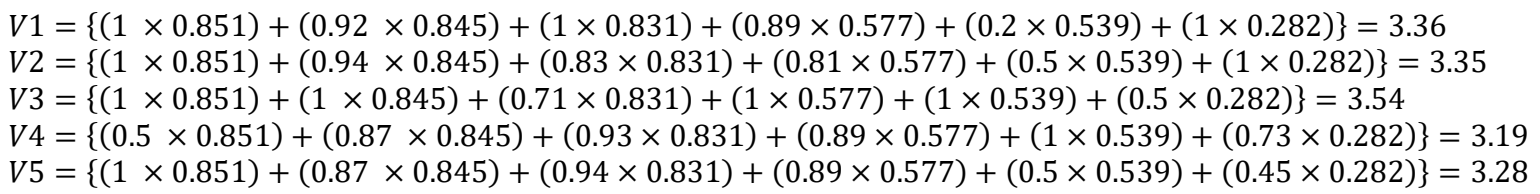

Berdasarkan perhitungan di atas maka hasil dari perangkingan dari setiap alternatif disajikan pada Tabel 6 sebagai berikut.

Tabel 6. Hasil Perangkingan Berdasarkan Bobot

\begin{tabular}{ccc}
\hline No & Alternatif & Nilai \\
\hline 1 & A3 & 3.54 \\
\hline
\end{tabular}


ISSN 2614-5278 (media cetak), ISSN 2548-8368 (media online)

Available Online at https://ejurnal.stmik-budidarma.ac.id/index.php/mib

DOI 10.30865/mib.v5i3.3080

\begin{tabular}{lll}
\hline 2 & A1 & 3.36 \\
3 & A2 & 3.35 \\
4 & A5 & 3.28 \\
5 & A5 & 3.19 \\
\hline
\end{tabular}

Berdasarkan perhitungan tersebut diketahui bahwa nilai, V1 $=3.36, \mathrm{~V} 2=3.35, \mathrm{~V} 3=3.54, \mathrm{~V} 4=3.19$, V5 =3.28, di mana V merupakan nilai preferensi dari setiap alternatif. sehingga dapat disimpulkan bahwa V3 memiliki nilai terbesar, dengan demikian alternatif 3 (A3) adalah calon siswa baru yang memiliki nilai dengan bobot tertinggi dibandingkan dengan calon siswa baru lainnya.

\section{KESIMPULAN}

Hasil akhir dari penggunaan metode SAW (Simple Additive Weighting) adalah peringkat perolehan nilai akhir masing-masing calon siswa baru. Hasil peringkat tersebut didapatkan dari jumlah perkalian masing-masing nilai dari setiap calon siswa baru dengan kriteria terbobot, di mana pembobotan didasarkan pada hasil uji korelasi untuk mengetahui hubungan antara setiap kriteria terhadap keputusan diterimanya calon siswa baru. Berdasarkan hasil penelitian yang telah dilakukan dapat disimpulkan bahwa kriteria yang paling penting agar siswa dapat diterima adalah kriteria penghasilan orang tua, yaitu sebesar 0,851 . Selanjutny berturut-turut nilai matematika $(0,845)$, nilai bilai bahasa inggris $(0,831)$, nilai fisika $(0,577)$, kesamaptaan $(0,539)$, dan peminatan $(0,282)$. Hasil berdasarkan perangkingan, didapatkan kesimpulan bahwa Alternatif 3 (A3) memiliki nilai paling tinggi berdasarkan hasil perkalian bobot dengan matriks ternormalisasi, sehingga diasumsikan sebagai siswa dengan nilai terbaik. Berdasarkan hal tersebut penggunaan metode SAW dengan pembobotan menggunakan teknik analisis korelasi dapat digunakan sebagai alternatif pilihan untuk mengurangi subjektivitas dari penggunaan metode SAW yang tidak memiliki dasar yang pasti dalam penentuan bobot dari setiap kriteria-kriteria yang ditentukan.

\section{REFERENCES}

[1] A. D. Susanti, M. Muslihudin, and S. Hartati, "Sistem Pendukung Keputusan Perankingan Calon Siswa Baru Jalur Undangan Menggunakan Simple Additive Weighting (Studi Kasus : Smk Bumi Nusantara Wonosobo)," Semin. Nas. Teknol. Inf. dan Multimed. 2017, vol. 5, no. 1, pp. 37-42, 2017.

[2] M. Muslihudin and A. W. Arumita, "PEMBUATAN MODEL PENILAIAN PROSES BELAJAR MENGAJAR PERGURUAN TINGGI MENGGUNAKAN FUZZY SIMPLE ADDITIVE WEIGHTING (SAW) (Sudi : STMIK Pringsewu),"Semin. Nas. Teknol. Inf. dan Multimed., pp. 6-7, 2016.

[3] Y. Irawan and D. Wahyuningsih, "Pendaftaran Peserta Didik Baru Dengan Metode Simple Additive Wighting (Saw)," JSiI (Jurnal Sist. Informasi), vol. 5, no. 1, pp. 25-32, 2018.

[4] T. B. I. Al-isyarah, "Problem Subjektifitas Dalam Tafsir Bi Al- Ma’ Tsur, Tafsir Bi Al - Ra ' Yi , Dan,” vol. 4, no. 01, pp. 1-18, 2016.

[5] K. D. Purwitasari and F. S. Pribadi, "Implementasi Sistem Pendukung Keputusan Peminatan Peserta Didik SMA menggunakan Metode AHP (Analytic Hierarchy Process) dan SAW (Simple Additive Weighting),” J. Tek. Elektro, vol. 7, no. 2, 2015.

[6] A. Nurzahputra, A. R. Pranata, and A. Puwinarko, "Sistem Pendukung Keputusan Pemilihan Line-up Pemain Sepak Bola Menggunakan Metode Fuzzy Multiple Attribute Decision Making dan K-Means Clustering,” J. Teknol. dan Sist. Komput., vol. 5, no. 3, p. $106,2017$.

[7] S. Prahesti, D. E. Ratnawati, and H. Nurwasito, "Sederajat Kota Malang Menggunakan Metode Ahp-Electre Dan," J. Teknol. Inf. dan Ilmu Komput., vol. 4, no. 1, pp. 25-30, 2017.

[8] R. Akbar, "Perancangan Aplikasi Perangkingan Perguruan Tinggi Menggunakan Fuzzy Simple Additive Weighting (SAW) (Studi Kasus: 25 PT Wilayah Kopertis XIII Provinsi Aceh),” J. JTIK (Jurnal Teknol. Inf. dan Komunikasi), vol. 2, no. 1, p. 1, 2018.

[9] A. P. Windarto, "Implementasi Metode TOPSIS dan SAW dalam Reward Pelanggan," Klik - Kumpul. J. Ilmu Komput., vol. 10, no. 2, p. 88,2018

[10] C. Surya, "Sistem Pendukung Keputusan Rekomendasi Penerima Beasiswa Menggunakan Fuzzy Multi Attribut Decision Making (FMADM) dan Simple Additive Weighting (SAW)," J. Rekayasa Elektr., vol. 11, no. 4, p. 149, 2015.

[11] I. J. T. Situmeang, S. Hummairoh, S. M. Harahap, and Mesran, "Application of SAW ( Simple Additive Weighting ) for the Selection of Campus Ambassadors," IJICS (International J. Informatics Comput. Sci., vol. 5, no. 1, pp. 21-28, 2021.

[12] R. Y. Simanullang, Melisa, and Mesran, "Sistem Pendukung Keputusan Penerima Bantuan Covid-19 Menggunakan Metode Simple Additive Weighting (SAW)," TIN Terap. Inform. Nusant., vol. 1, no. 9, pp. 2-9, 2021.

[13] M. R. Ramadhan, M. K. Nizam, and Mesran, "Penerapan Metode SAW (Simple Additive Weighting) Dalam Pemilihan Siswa-Siswi Berprestasi Pada Sekolah SMK Swasta Mustafa," TIN Terap. Inform. Nusant., vol. 1, no. 9, pp. 459-471, 2021.

[14] T. Limbong et al., Sistem Pendukung Keputusan: Metode \& Implementasi. Medan: Yayasan Kita Menulis, 2020.

[15] M. Muslihudin, T. S. Susanti, and A. Maseleno, "The priority of rural road development using fuzzy logic based simple additive weighting," Int. J. Pure Appl. Math., vol. 118, no. Special Issue 8, pp. 9-16, 2018.

[16] kalsah R. Zubaeti, "Simple Additive Weighting Method in the Development of a System Assessing the Feasibility of Job Training Industry," Indones. J. Informatics Educ., vol. 1, no. 2, pp. 17-28, 2017.

[17] D. A. Teuku Mufizar, Teten Nuraen, "Sistem Pendukung Keputusan Rekomendasi Penerima Bantuan Siswa Miskin (BSM) Dengan Metode Simple Additive Weighting (SAW),” Semin. Nas. Inform., vol. 9, no. April, p. 3, 2015.

[18] H. Usman and P. S. Akbar, Pengantar Statistika. Jakarta: Bumi Aksara, 2009.

[19] T. Mufizar, D. S. Anwar, and E. Aprianis, "Sistem Pendukung Keputusan Pemilihan Jurusan Dengan Menggunakan Metode SAW Di SMA 6 Tasikmalaya,” Voice Of Informatics, vol. 5, no. 1, pp. 1-13, 2016. 